\title{
Genetic Investigation of Wild Species of Subfamily Malvoideae in Saudi Arabia as Inferred From SCOT and ISSR Markers
}

kadry abdelkhalek ( $\sim$ kadry3000@yahoo.com )

Biology Department, Faculty of Science, Umm-Al-Qura University, Mecca, Saudi 7 Arabia https://orcid.org/0000-0003-1060-6869

Suad Al-Ruzayza

Umm Al-Qura University

Original article

Keywords: Phylogenetic, Taxonomy, molecular marker, Malvaceae

Posted Date: December 30th, 2020

DOI: https://doi.org/10.21203/rs.3.rs-135572/v1

License: (c) (i) This work is licensed under a Creative Commons Attribution 4.0 International License.

Read Full License 
Genetic investigation of wild species of subfamily Malvoideae in Saudi Arabia as inferred from SCoT and ISSR markers

\section{KADRY ABDEL KHALIK ${ }^{1,2,}$, ,SUAD AL-RUZAYZA ${ }^{1}$}

1 Biology Department, Faculty of Science, Umm-Al-Qura University, Mecca, Saudi Arabia

2 Botany and Microbiology Department, Faculty of Science, Sohag University, 82524 Sohag, Egypt

* Correspondence: kadry3000@yahoo.com

\section{Abstract}

Genetic investigation and phylogenetic analyses of 21 species, representing 8 genera of the subfamily Malvoideae, from Saudi Arabia were carried out by using Start Codon Targeted (SCoT), the Inter Simple Sequence Repeats DNA (ISSR), and united ISSR and SCoT markers. Ten SCoT and five ISSR primers created 149 polymorphic enlarged fragments, which jagged to a comparatively high level of genetic difference in Malvoideae. SCoT markers exposed a higher level of polymorphism (89 bands) than ISSR (60 bands). Gathering of genotypes within groups was greatly similar when SCoT and ISSR consequent dendrograms were compared. Five clusters and clades can be documented within Malvoideae, which regularly verify, but also partially deny, traditional groupings. Taxonomic and phylogenetic consequences are debated in contrast with the existing morphological and phylogenetic data. The results of this study offer useful data for evaluating the taxonomy of Malvoideae at both tribes, infrageneric, and subgeneric levels. In general, the results reported here are largely consistent with the phylogenetic findings that Abutilon, Hibiscus, and Malva are polyphyletic. Also, species of sections Bombicella and Malva are highly heterogeneous. The most exciting result of this analysis was identifying Senra incana with unique characters and telling that it should be preserved as a separate tribe. In the similar way, distinctive variances between the closely related genera Fioria and Althaea were also noted suggesting that they should be placed in different tribes. Furthermore, the present results indicate some level of parallel among the species of Pavonia and support the monophyly of this genus. 


\section{Introduction}

Malvaceae is a universal family of herbs, shrubs, and small trees with a primary focus of genera in the tropical regions and including about 244 genera with some 4225 species (Christenhusz \& Byng, 2016). It is a natural family, simply distinguished by its monadelphous stamens, monothecal anthers, simple entire mostly palmate leaves, stellate hairy indumentum, and large echinate pollen grains. It is closely related to Tiliaceae, Bombacaceae, and Sterculiaceae but differs in the possession of one-celled anthers and monadelphous stamens (Hutchinson, 1967; Fryxell, 1997; Heywood, 1993; La Duke \& Doeby, 1995; Mabberley, 1997). Bayer (1999), Bayer \& Kubitzki (2003) ordered Malvaceae into Nine subfamilies: Bombacoideae Brownlowioideae, Byttnerioideae, Dombeyoideae, Grewioideae, Helicteroideae, Malvoideae, Sterculioideae, and Tilioideae based on morphological and molecular data. The systematic of Malvaceae mostly at the subfamilies, tribal, and generic level, is often unsure (Bentham \& Hooker, 1862; Schumann, 1889; Bates 1968). Kearney (1951) divided the family Malvaceae into four tribes viz. Malpeae, Ureneae, Hibisceae, and Malveae, which are divided into four subtribes viz. Abutilinae, Malvinae, Siodinae, and Ureneae. Furthermore, Hutchinson (1967) divided Malvaceae into 5 tribes viz. Malopeae, Hibisceae, Malveae, Abutileae, and Ureneae based on the characters of fruits, while Schultze-Motel (1964) recognized three tribes. Besides, La Duke\& Doebley (1995) and Krebs (1994) separated into five or six tribes: Malopeae, Malveae, Hibiscieae, Abutilieae, Ureneae, and Decaschistieae. Recently, Bayer \& Kubitzhi (2003) and Takhtajan (2009) classified subfamily Malvoideae (formerly Malvaceae), into four main tribes viz. Kydieae, Gyosspieae, Hibisceae including (Fioria, Hibiscus, Pavonia, and Senra) and Malveae including Abutilon, Althaea, and Malva) based on morphological and molecular data. In the flora of Saudi Arabia, Collenette (1999) recognized 11 genera comprising 38 species. However, Chaudhary (1999) reported 13 genera and 54 species of Malvaceae includes cultivated species. Molecular markers have excessive standing in detecting different parental genotypes over the estimation of genetic difference, which appreciated in cultivar identification (Abdel Khalik et al., 2014). The use of molecular markers for the finding and corruption of DNA polymorphism is one of the most significant progress in the field of molecular genetics. Among the diverse molecular markers, Start Codon Targetted DNA (SCoT) and Inter Simple Sequence Repeat (ISSR) is the simple, rapid, highly effective, and searching procedures. These markers have been used to classify and 
define the genetic range in many plants (Zietkiewicz et al., 1994; Bornet \& 79 Branchard, 2001; Collard \& Mackill, 2009; Celka et al., 2010; Hamidi et al., 2014; v • Ibrahim et al., 2016). In the works analysis, we could not find any phylogenetic $V$ I investigation (molecular markers, ISSR, and SCOT) of Malvaceae species. The Vr present study aims to assess the interspecific genetic diversity among some species of $\mathrm{VT}$ Malvoideae from Saudi Arabia by the means of the SCOT and ISSR methods to $V \varepsilon$ obtain shared results. To verify whether these results match with the systematics of the genera as proposed by most traditional and new classification systems for Malvoideae tribes and to report the taxonomic difficulties of the subfamily.

\section{Material and Methods}

\section{Plant materials}

The leaf samples of the studied taxa are collected from wild inhabitants and some herbarium samples. The voucher specimens of the studied species are placed in the herbarium of the Department of Biology of Umm Al-Qura University (UQU) (TABLE 1).

\section{Plant genomic DNA extraction}

Total genomic DNA was extracted from leaf samples. The leaves were first crushed into a fine powder in liquid nitrogen using a pestle and mortar following the CTAB protocol (Porebski et al., 1997; Hussien et al., 2003).

\section{Estimation for the DNA concentration:}

Run $2 \mu 1$ of the parent's DNA samples on $1 \%$ agarose gel in assessment to $10 \mu 1$ of a DNA size marker (100bp DNA Ladder). To estimate DNA concentration, link the degree of fluorescence of the DNA sample with the different bands in the DNA size marker.

\section{ISSR and SCoT- PCR reactions}

A set of 5 primers ISSR and SCoT (TABLE 2) was used in the finding of polymorphism. The amplification reaction was carried out in $25 \mu 1$ reaction volume containing 1X PCR buffer, $1.5 \mathrm{mM} \mathrm{MgCl2}, 0.2 \mathrm{mM}$ dNTPs, $1 \mu \mathrm{M}$ primer, $1 \mathrm{U}$ Taq DNA polymerase, and $30 \mathrm{ng}$ template DNA.

\section{Thermocyling Profile}

PCR amplifications were achieved in a Perkin-Elmer/GeneAmp® PCR System 9700 (PE Applied Biosystems) planned to fulfill 35 cycles after an initial denaturation cycle for $5 \mathrm{~min}$ at $94^{\circ} \mathrm{C}$. Each cycle consisted of a denaturation step at $94^{\circ} \mathrm{C}$ for $1 \mathrm{~min}$, an 
hardening step at $50^{\circ} \mathrm{C}$ for $1 \mathrm{~min}$, and an elongation step at $72^{\circ} \mathrm{C}$ for $1.5 \mathrm{~min}$. The primer extension segment was extended to $7 \mathrm{~min}$ at $72^{\circ} \mathrm{C}$ in the final cycle.

\section{Detection of the ISSR and SCoT Products}

The amplification products were fixed by electrophoresis in a $1.5 \%$ agarose gel comprising ethidium bromide $(0.5 \mathrm{ug} / \mathrm{ml})$ in $1 \mathrm{X}$ TBE buffer at 95 volts. A $1 \mathrm{~kb}$ DNA ladder was used as a molecular size standard. PCR products were imagined on UV light and photographed using a Gel Documentation System (BIO-RAD 2000) (FIGUREs 1 \& 2).

\section{Data Analysis}

The banding patterns created by ISSR and SCoT-PCR marker analyses were allied to determine the genetic resemblance of the samples under study (TABLE 3). The pairwise similarity among the genotypes characterized in the different lanes can be enumerated using indexes of similarity was estimated according to the Dice coefficient (Sneath \& Sokal, 1973). For phylogenetic investigation, each amplified band was preserved as a unit character, forgetting its concentration, and was scored in terms of a binary code based on the presence (1) and absence (0) in the gel. Only pure and reproducible bands were measured for counting. Three datasets were used, SCoT, ISSR, and a combined dataset of SCOT and ISSR. The numerical method working only the presence or absence of a band as its difference feature. The binary qualitative data matrices were then used to build similarity matrices based on similarity coefficients. The similarity matrices were then used to generate dendrograms by using Unweighted Pair Group Method with Arithmetic Average (UPGMA)(Sneath\&Sokal,1973).

\section{Results}

\section{SCoT analysis:}

Ten primers were used for the ScoT analysis to examine the outline of genetic differences among the measured species of the family Malvaceae growing in Saudi Arabia. Among the primers verified, only five exposed a polymorphism. Each primer was verified on all samples and was selected for genotype analysis if its patterns were reproducible and constant. Polymorphic bands were selected for recognizing the genetic resemblance for the group of species. A whole of 89 reproducible polymorphic bands were formed by using 5 ScoT-PCR primers. The average similarity coefficient extended from 0.55 to 1.00 . The maximum number of polymorphic amplification DNA fragments gotten per primer was 20 bands for the 
primers SCoT-18 and SCoT-35. The relationships between the studied taxa are existing with the help of a dendrogram constructed based on similarity factors. For ease of calculation, the 100 bands were booked together and the number of bands for each size of DNA fragments (bp) was counted for every species. One branches and four clusters with about 0.65 similarities were found (FIGURE 3): (i) a branch including Senra incana; (ii) a cluster comprising Eight species of Abutilon and Althaea ludwigii with about 0.65 genetic similarities; (iii) a cluster includes Fioria vitifolia and Hibiscus deflersii with about 0.75 genetic similarities; (iv) a cluster with of Hibiscus purpureus, Hibiscus micranthus, Sida alba, and Malva parviflora; (v) a cluster includes Malva sylvestris, Malva neglecta, Pavonia arabica and Pavonia kotschyi with about 0.67 genetic similarities.

\section{ISSR analysis:}

In whole five primers for ISSR were used to examine the designs of genetic variations among the species of Malvaceae growing in wild habitat in Saudi Arabia. In total, 60 $1 \leqslant 9$ (49 are polymorphic and 11 are monomorphic) reproducible bands were caused by the 10. five ISSR primers; and these bands were used for studying the genetic similarity among the species. The average similarity coefficient ranged from 0.60 to 1 . The results indicated that all primers were polymorphic. The highest number of polymorphic amplification DNA fragments gotten per primer was 12 for the primer ISSR- 4. The results of the consensus tree from ISSR data displayed that the tree was divided into two branches and three clusters with 0.65 similarities (FIGURE 4): (i) a branch including Fioria vitifolia; (ii) a branch including Hibiscus deflersii; (iii) a cluster Althaea ludwigii and Eight species of Abutilon with 0.75 genetic similarities; (iv) a cluster including Hibiscus purpureus and Hibiscus micranthus with about 0.75 genetic similarities; (v) a cluster including a subgroup of Sida alba, Malva parviflora and Malva verticillata, Malva sylvestris, Malva neglecta, Pavonia arabica with a similarity score of 0.75 , and the subgroup of including Pavonia kotschyi and Senra incana with a similarity score of 0.88 .

\section{Combined SCoT and ISSR analysis:}

The UPGMA dendrogram gotten from the cluster analysis of SCoT and ISSR shared data existing a near similar clustering pattern, with similarity coefficient ranging from 
clusters with a similarity score of 0.65 (FIGURE 5): (i) a branch including Senra incana; (ii) a branch Fioria vitifolia; (iii) a cluster comprising Hibiscus deflersii, Malva sylvestris and Malva neglecta, Sida alba, Malva parviflora and Malva verticillata with a similarity score of 0.67 ; (iv) a cluster includes three groups; one group includes Pavonia arabica and Pavonia kotschyi and the second one contains Eight species of Abutilon, the third group includes Althaea ludwigii with a similarity score of 0.73 ; (v) a cluster consist of Hibiscus purpureus and Hibiscus micranthus with about 0.85 genetic similarities.

\section{Discussion}

Several authors have tried to offer an accepTABLE system to classify the family Malvaceae into subfamilies, tribes, and subtribes (Bentham \& Hooker, 1862; Kearney, 1951; Schultze-Motel, 1964; Hutchinson, 1967; Bates, 1968; Krebs, 1994; Duke\& Doebley, 1995). These studies are based on one or two traits such as life forms, carpel morphology, number and position of ovules in each carpel, fruits, and seeds. Morphological characters in plants could be affected by environmental conditions. Thus, the use of morphological characters for classification may effect in divergences.

SCot and ISSR molecular markers are broadly used for population genetic analysis of different plants creating more dependable and reproducible bands (Nagaoka \& Ogihara, 1997; Collard \& Mackill, 2009; Zhang et al., 2015; Sadek \& Ibrahim, 2018). along with the right statistical tools could be definitely useful to evaluate the genetic diversity and phylogenetic analysis in subfamily Malvoideae. Although SCoT and 19. ISSR markers showed significant differences in detecting polymorphism and discriminating capacity, they showed nearly similar topology in dendrograms generated based on similarity matrices. A extremely significant link between these two dendrograms suggested that both markers were similarly efficient for measuring phylogenetic relationships among the investigated taxa. Moreover, the genotype scattering on the consensus tree based on the shared banding patterns of SCoT and ISSR may significantly vary because each technique may magnify different parts of the genome. The SCoT markers are very reproducible due to the use of longer primers, and ISSR amplifies the region between two microsatellites. Hence, the polymorphisms reveal the variety of these regions of the genome. It is, therefore, 
sites of the genome that will increase the strength of the consensus tree. General, our results obtained from the SCoT and ISSR analyses proposed groups and partially established the tribes, subtribes, and sections classification of Malvoideae by the most recent traditional (Mattei, 1915; Kearney, 1951; Schultze-Motel, 1964; Hutchinson, 1967; Bates, 1968; La Duke \& Doebley, 1995) and a recent phylogenetic classification based on molecular data (Fryxell, 2002; Bayer \& Kubitzhi, 2003; Tate et al., 2005; Reveal's, 2012).

\section{Abutilon group (G2 B)}

The taxonomy of Abutilon is very difficult mostly due to a high degree of plasticity and so adaptations to climatic conditions. According to Hutchinson (1967), the tribe Abutileae comprises two subtribes: Abutilinae (include Abutilon) and Sidinae (include Sida and Malvastrum). The tribe Abutileae however, was comprised within Malveae in the system of Takhtajan (2009). Based on molecular data Reveal (2012) separated both subtribes Sidinae and Abutilinae from Malveae under tribe Sidieae. The infrageneric classification of Abutilon is unwell understood. The genus has been ordered into sections and subsections by some workers, but only for quite limited geographical areas such as Schumann (1891) for Brazilian species, Mattei (1915) for East African species (using the ranks stirps and substirps), and Fryxell (1988) for Mexican species. Mattei (1915) grouped the East African Abutilon into three natural stirps (Capsulati, Cephalocarpi, and Monospermi) and seven substirps (Fruticosi, Cuispidati, Indici, Graveolenti, Mericarpi, Blepharocarpi, and Mutici) based on the carpels, seeds, and leaves morphology.

The systematic revision on Abutilon (Mattei, 1915) including all species distributed in Saudi Arabia, allows us to compare our results with him. He treated Abutilon fruticosum under stirps Capsulati substirps Frutieosi; A. ramosum in stirps Capsulati substirps Cuspidati; A. figarianum in stirps Cephalocarpi substirps Graveolenti; Abutilon bidentatum, A. hirtum, and A. grandifloium in stirps Cephalocarpi substirps Mierocarpi; A. muticum and A. pannosum in stirps Cephalocarpi substirps Mutici. Moreover, Fryxell (2002) presented an eventual study and nomenclature of more than 500 names at the specific rank and 25 names in the infrageneric rank of Abutilon. He treated Abutilon bidentatum and A. grandifloium in section Beloere; A. muticum, A. pannosum, and A. figarianum in section Muticum; A. fruticosum in section Oligocaroae. Also, Fuertes Aguilar et al. (2003) studied phylogenetic relations between members of the subtribe Abutilinae and mostly the taxa in the Sida generic 
alliance based on the internal transcribed spacers of nuclear ribosomal DNA (ITS) from 58 species of Malvaceae were sequenced. The ITS data show that Abutilon and Sida were not monophyletic. Similarly, Tate et al. (2005), studied the phylogenetic relations within tribe Malveae based on sequence data from (ITS) regions of the 1826S nuclear ribosomal repeat and accepted two main clades: one comprising Abutilon and Sida (Abutilon alliance) and a second covering the rest of taxa, and they revealed that Abutilon, Sida, and Tetrasida are not monophyletic. Furthermore, Taia (2009) investigated the systematic revision of Five species of Abutilon from Saudi Arabia based on morphology and provided that close relation among species and classified them into two groups.

According to the combined SCoT and ISSR tree (group 2B), the studied taxa of Abutilon were grouped in one cluster. This cluster is splitting off into two groups. One group includes Abutilon bidentatum, A. hirtum, A. grandifloium, and A. muticum (Stirps Cephalocarpi), and A. ramosum (stirps Capsulati) with 0.82 genetic similarities. These species are morphologically distinguished by the absence of epicalyx, mericarps that lack wings, dorsally dehiscent fruit, and by leaves that are sub-entire to serrate margins. The second group includes A. pannosum and $A$. figarianum (Stirps Cephalocarpi) and A. fruticosum (Stirps Capsulati) with 0.80 genetic similarities. These species are actual comparable, as the three have largely ovate or rounded leaf blades, with either rounded or acute apices. Meanwhile our results are inherited data, and we propose that species of Abutilon form a polyphyletic group. Our data support the previous work of treating tribe Abutileae (Sidieae sensu Reveal 2012) with its two subtribes as distinct from Malveae. Therefore, these results partially agree with Mattei (1915) and Fryxell (2002), and congruent with those of Fuertes Aguilar et al. (2003), Tate et al. (2005), and Reveal (2012).

\section{Pavonia group (G 2 A)}

This group comprises only Pavonia arabica and P. kotschyi. It has been documented as a distinct clade with 0.80 genetic similarities. These species can be clearly defined based on various features: the perennial, presence of epicalyx, leaves not lobed, mericarps 5, and seed 1 in each mericarp. A Fryxell (1997) investigated Pavonia of the new world and show that all species of the genus have the same base chromosome number $\mathrm{x}=7$. Pavonia placed in a separate tribe Ureneae by most authors (Bentham $\&$ Hooker, 1862; Schultze-Motel, 1964, Hutchinson, 1967 \& Cheek 2007). While Takhtajan (2009) and Reveal (2012) placed the genus with Hibiscus in the tribe 
Hibiscieae. Our data support the previous work of treating Pavonia in a separate tribe Ureneae and agree with those authors.

\section{Althaea clade (G 2 C)}

Bentham \& Hooker (1862), Hutchinson (1967), and Reveal (2012) treated this genus in tribe Malveae. However, Jun Qiana et al. (2020) investigated phylogenetic analysis of Althaea rosea based on whole cp genome sequences and show that a close relationship of Althaea with Gossypium and Hibiscus in Malvaceae. Rendering to the combined SCoT and ISSR tree, the results do not support the placement of Althaea ludwigii in tribes Malveae or Hibisceae. This is due to the assignment of Althaea ludwigii within a distinct branch with high genetic similarities. This species is well known morphologically from the other species by having an annual life form, 3 segments epicalyx, indehiscent fruit, many mericarps, each one includes one seed. This result disagrees with those of Bentham \& Hooker (1862), Hutchinson (1967), and Reveal (2012) Jun Qiana et al. (2020) for treating it as tribe Malveae or Hibisceae. More data are necessary for deciding this assumption.

\section{Senra clade (G 3)}

This branch includes only Senra incana. It has been known as a separate clade with high genetic similarities and can be clearly distinguished based on several features: spheroidal pollen shape, seed hairy, style 5-branched, capsule with 1-locule, and 1seed, calyx without oil glands.

Bentham \& Hooker (1862), Hutchinson (1967), treated this genus in the tribe Hibiscieae. However, Reveal (2012) placed Senra in tribe Gossypieae, based on molecular data. Our data support the previous work of treating Senra in tribe Gossypieae (sensu Reveal, 2012).

\section{Fioria clade (G 5)}

According to our results, Fioria vitifolia shows the largest distance from all other groups, and is distinct from the others by the characters of the persistent calyx with 5toothed, calyx without oil glands, fruit 5-broadly winged, and seed reniform, tuberculate. Bentham \& Hooker (1862), Hutchinson (1967), and Reveal (2012) treated this genus in the tribe Hibiscieae. Our data support the previous work of treating Fioria in a tribe Hibiscieae and congruence with those authors.

\section{Hibiscus groups (G 1 \& G 4)}

Concerning the cluster and clade of Hibiscus purpureus, H. micranthus, and $H$. deflersii, our results do not support the monophyly of the non-natural section 
Bombycella. This is due to the situation of Hibiscus purpureus, H. micranthus, and $H$. deflersii within two separate clusters and clade with 0.82 genetic similarities.

Bentham \& Hooker (1862), Hutchinson (1967), and Reveal (2012) treated this genus in the tribe Hibisceae. Hochreutiner (1900) revised the genus Hibiscus and classified it into 12 sections and he concluded that Hibiscus is very heterogeneous and needs additional attention. Ulbrich in Engler (1921) divided section Bombycella into three subsections: Syriaca, Eubombycella, and Africana. Moreover, Cufodontis (1948) overview Hibiscus species in Africa and treated Hibiscua purpureus, H. micranthus, and $H$. deflersii in section Bomycella. Furthermore, Fryxell (1980) concluded that section Bombicella is the second most diverse section of Hibiscus, after section Furcaria, and is a paraphyletic section. Also, they cited that the chromosome number extremely variable, because the chromosome base number of American species $\mathrm{x}=11$ diploids, and African species $\mathrm{x}=16$ diploids or tetraploids, while Australian species $2 n=54$ allotetraploids. Since our results are inherited data, and we propose that species of section Bombicella subsection Eubombycella (sensu Engler, 1921; Cufodontis, 1948) form a paraphyletic group. Therefore, these data agree with those of Hochreutiner (1900) and Fryxell (1980) for treating section Bombycella as a heterogeneous section.

\section{Malva-Sida group (G 1)}

Bentham \& Hooker (1862), Hutchinson (1967), and Reveal (2012) treated Malva in the tribe Malveae. However, they preserved Sida in the tribes Malveae, Abutileae, and Sideae respectively. Based on flower structure characteristics, Baker (1890) divided the genus Malva into three sections: Bismalva, Bibracteolata, and Fusciculata, which includes (Malva neglecta, M. parviflora, M. sylvestris, and M. verticillata). However, Dalby (1968) separated the European species of the genus Malva into two sections: Bismalva and Malva. The section Bismalva includes species with single flower in the leaf axils or a congested, terminal raceme, while the species of the section Malva have two or more flowers in each leaf axil. Bates (1968) suggested that Malva might be polyphyletic because it has chromosome number in the range $2 n=14$ should be considered diploids, and $2 \mathrm{n}=40-44$ species are hexaploids and this number is related to Sida and other taxa. Furthermore, Luque \& Devesa (1986) reported that chromosome base number hexaploids $2 \mathrm{n}=42$ in $M$. neglecta, M. parviflora, $M$. sylvestris, and dodecaploids with a chromosome count of $(76,84,112)$ in $M$. verticillata. Besides, Fryxell (1997) reported that Sida has the same base chromosome 
number $\mathrm{x}=7$ or $8(2 \mathrm{n}=14,28 ; 2 \mathrm{n}=16,32)$, and is heterogeneous. Ray (1995) based on an ITS sequence analysis, differentiated two groups: Malvoid and Lavateroid, and he placed all species of Malva in the malvoid group. Similarly, Garcia et al. (2009) used five molecular markers (ITS, matK $+\operatorname{trnK}, n d h F, \operatorname{trnL}-\operatorname{trnF}, p s b A-\operatorname{trnH}$ ), to investigate a phylogenetic hypothesis of Malva alliance (Malvaceae), and they show that Althaea, Lavatera, and Malva are highly polyphyletic. Also, they treated Malva neglecta and $M$. sylvestris in a subgroup with 0.96 genetic similarities, and $M$. parviflora and $M$. verticillata in another subgroup with 0.82 genetic similarities based on total plastid markers. Furthermore, Celka et al., (2010) used ISSR and ISJ markers to determine genetic relationships among eight Malva taxa. The species are classified into two groups consistent to the sections Bismalva (M. alcea, M. excisa, and M. moschata) and Malva (M. neglecta, M. pusilla, M. sylvestris, and M. verticillata). According to the combined SCoT and ISSR tree, the results do support the placement of M. neglecta, M. parviflora, M. sylvestris, and M. verticillata) in section Malva, but is not monophyletic. This is due to the placement of M. parviflora, M. verticillata, and Sida alba within a separate sub-cluster, and M. neglecta, M. sylvestris, and Hibiscus deflersii in another sub-cluster with 0.71 genetic similarities. This cluster is distinguished morphologically from the other species by having schizocarp fruit, leaves unlobed, many mericarps, base chromosome number $\mathrm{x}=7$.

In general, there is some congruence between morphological results and those of phylogenetic studies. Our results reported here are largely consistent with the findings of Bates (1968), Ray (1995), Garcia et al. (2009), and Celka et al., (2010) that Malva is highly polyphyletic, along with the division into sections based on morphology suggested by Baker (1890), Dalby (1968).

\section{Conclusions}

Genetic investigation and phylogenetic analyses of 21 species, representing 8 genera of the subfamily Malvoideae, from Saudi Arabia were carried out by using Start Codon Targeted (SCoT), the Inter Simple Sequence Repeats DNA (ISSR), and combined ISSR and SCoT markers. Five clusters and clades can be accepted within Malvoideae, which mostly verify, but also partially reverse, traditional groupings. The results of this study offer valuable data for judging the taxonomy of Malvoideae both at tribes, infrageneric, and subgeneric levels. In general, our results reported here are largely consistent with the phylogenetic findings that Abutilon, Hibiscus, and Malva are polyphyletic. Besides, species of sections Bombicella and Malva are highly 
heterogeneous. A remarkable result from this study was to identify Senra incana with distinctive characters and telling that it should be preserved as a separate tribe. In the same way, distinguishing differences between the closely related genera Fioria and Althaea were also noted suggesting that they should be placed in different tribes. Additional support comes from the molecular data of RAPD and ISSR which indicate that some level of similarity among the species of Pavonia and support the monophyly of this genus. Nevertheless, we believe that molecular and morphological tactics should be joint to arrive at a generally accepted phylogenetic reconstruction of Malvoideae. Moreover, a broad study covering extra species from different genera would be necessary to make a more exhaustive classification.

\section{Acknowledgments}

The authors would like to thank the Research and Development Grants Program for National Research Institutes and Centers (GRANTS), Graduate Research Program, King Abdulaziz City for Science and Technology (KACST), Kingdom of Saudi Arabia, grant number (Project ID: 1-18-01-007-0001) for the financial funding. Also, we are thankful to the herbarium director and curator of the King Saud University and Agriculture and Water Research Center, Riyadh, (KSU and RAWRC).

\section{rVA}

rvq

ґ.

HN

rAT

rNT

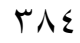

rNo

rᄉт

rNv

rAN

\section{Authors' contributions}

พ^q

The authors contributed to the work done in the manuscript as follows: All authors rq. participated in the design, interpretation of the studies and analysis of the data and review of the manuscript; Kadry and Suad, conducted the laboratory experiments. Kadry and Suad presented the data in table and graphs and prepared the preliminary version of the manuscript. Kadry and Suad revised the experimental design, guided the data analyses, interpretation, and manuscript revision. Kadry, guided the laboratory experiments, helped in the preparation of the first version of the manuscript and analysis of the experi-mental data. All authors read and approved the final manuscript.

\section{Funding}

This work was funded by Research and Development Grants Program for National Research Institutions and Centers (GRANTS), Graduate Research-Program, King Abdulaziz City for Science and Technology (KACST), Riyadh, Kingdom of Saudi Arabia, grant no: 1-18-01-007-0001.

(q)

rqT

rq

एqร

rqo

ए97

एवV

rqA

All relevant data are within the manuscript. 
Not applicable.

\section{Consent for publication}

Not applicable.

\section{Competing interests}

The authors declare that they have no competing interests.

References

Abdel Khalik, K.N., Abd El-Twab, M.H. \& Galal, R.K. (2014) Genetic diversity and relationships among species of Egyptian Galium (Rubiaceae) and related species using ISSR and RAPD markers. Biologia (Bratislava) Botany 69(3): 300-310.

Baker, J.G. (1890) Synopsis of Genera and Species of Malveæ. Journal of Botany

http://archive.bsbi.org.uk/Journal_of_Botany_1890.pdf

Bates, D.M. (1968) Generic relationships in the Malvaceae, tribe Malveae. Gentes

Bayer, C. \& Kubitzki, K. (2003) Malvaceae. In: “Flowering plants, dicotyledons:

Malvales, Capparales, and non betalain Caryophyllales. (Kubitzki K, Bayer C. ed.)”. Springer Verlag, Berlin, Germany, pp. 225-311.

Bayer, C. (1999) The bicolor unit: homology and transformation of an inflorescence 198.

https://www.jstor.org/sTABLE/23643516

Bentham, G. \& Hooker, J.D. (1862). Malvaceae. In G. Bentham and J. D. Hooker [eds.], Genera Plantarum, 195-213. London, England.

Bornet, B. \& Branchard, M. (2001) Nonanchored inter simple sequence repeat (ISSR) 
Celka, Z., Szczecinska, M. \& Sawicki, J. (2010) Genetic relationships between some

of Malva species as determined with ISSR and ISJ markers. Biodiversity: Research and Conservation 19: 23-32.

https://doi.org/10.2478/v10119-010-0006-2

Chaudhary, S.A. (2001) Flora of the Kingdom of Saudi Arabia, vol. II. Ministry of

Agriculture and Water, Riyadh, Saudi Arabia.

$\leqslant \leqslant 0$

Cheek, M.R. (2007) Bombacaceae, Brownlowiaceae, Byttneriaceae, Durionaceae, $\varepsilon \leqslant 7$

Helicteraceae, Malvaceae, Pentapetaceae, Sparrmanniaceae, Sterculiaceae, Tiliaceae.

In: Heywood, V.H. et. al. (eds.), Flowering plant families of the world. Royal Botanic

Gardens, Kew.

$\varepsilon \leqslant 9$

Christenhusz, M.J.M. \& Byng, J.W. (2016) The number of known plant species in the world and its annual increase. Phytotaxa 261 (3): 201-217.

¿०.

$\{01$

\section{DOI: 10.11646/phytotaxa.261.3.1}

¿OY

Collard, B.C.Y. \& Mackill, D.J. (2009) Start codon targeted (SCoT) polymorphism: a simple, novel DNA marker technique for generating gene-targeted markers in plants.

Plant Molecular Biology Reporter 27 (1): 86-93.

sor

sos

§००

DOI: $10.1007 / \mathrm{s} 11105-008-0060-5$

纟07

Collenette, S. (1999) Wildflowers of Saudi Arabia, National Commission for Wildlife «०V Conservation and Development (NCWCD), Riyadh.

Cufodontis, G. (1948) Overview of the African Hibiscus species from section $\varepsilon 09$ Bombycella. Annals of the natural history museum in Vienna 56: 24-59.

Dalby, D.H. (1968) Malva. In: Tutin TG. et al. (eds.), Flora Europaea, vol. 2. $\{71$

Cambridge University Press, Cambridge, pp. 249-251.

Fryxell, P.A. (1980) A Revision of the American Species of Hibiscus section $\leq 74$ Bombicella (Malvaceae). Technical Bulletins 1624:1-53.

Fryxell, P.A. (1988) Malvaceae of Mexico. Systematic Botany Monographs 25: 1255.

Fryxell, P.A. (1997) The American genera of Malvaceae. II. Brittonia 49: 204-269. 
Fuertes Aguilar, J., Fryxell, P.A. \& Jansen, R.K. (2003) Phylogenetic relationships and classification of the Sida generic alliance based on nrDNA ITS evidence. Systematic Botany 28: 352-364.

DOI: $10.1043 / 0363-6445-28.2 .352$

García, E.P., Schönswetter, P., Fuertes Aguilar, J., Nieto Feliner, G. \& Schneeweiss, G.M. (2009) Five molecular markers reveal extensive morphological homoplasy and reticulate evolution in the Malva alliance (Malvaceae). Molecular Phylogenetics and Evolution 50: 226-239. DOI: 10.1016/j.ympev.2008.10.015

Hamidi, H., Talebi, R. \& Keshavarzi, F. (2014) Comparative efficiency of functional gene-based markers, start codon targeted polymorphism (SCoT), and conserved DNA-derived polymorphism (CDDP) with ISSR markers for diagnostic fingerprinting in wheat (Triticum aestivum L.). Cereal research communications 42(4): 558-567. https://doi.org/10.1556/crc.2014.0010

Heywood, V.H. (1993) Flowering plant families of the world. Oxford University Press, New York. markers. Arab Journal of Biotechnology 6(2): 180-201.

Hutchinson, J. (1967) The Genera of Flowering Plants (Angiospermae), vol. II. grape varieties by SSR and SCoT markers. Plant Omics 9(5):311-318.

Kearney, T.H. (1951) The American genera of Malvaceae. American Midland

Krebs, G. (1994) Taxonomic studies in the subtribe Malvinae. Feddes Repertorium 105:7-18. 
La Duke, J.C. \& Doebley, J. (1995) A chloroplast DNA based phylogeny of the Malvaceae. Systematic Botany 20: 259-271.

$0 . \varepsilon$

0.0

Mabberley, D.J. (1997) The Plant-Book. 2nd edition, Cambridge University Press, Cambridge, 680.

Mattei, G.E. (1915) Studi sugli Abutilon dell'Africa Orientale. Bollettino del R.Orto Botanico di Palermo 69-102.

Nagaoka, T. \& Ogihara, Y. (1997) Applicability of inter-simple sequence repeats polymorphisms in wheat for use as DNA markers in comparison to RFLP and RAPD markers. Theoretical and applied genetics 94(5): 597-602.

DOI: $10.1007 / \mathrm{s} 001220050456$

Porebski, S., Baily, L.G. \& Baum, R. (1997) Modification of a CTAB DNA extraction protocol for a plant containing high polysaccharide and polyphenol components. Plant Molecular Biology Reporter 15(1): 8-15.

https://doi.org/10.1007/BF02772108.

Reveal, J.L. (2012) An outline of a classification scheme for extant flowering plants. Phytoneuron 37: 1-221.

Schultze-Motel, W. (1964) in Melchior, H. (ed.). A. Engler's "Syllabus der Pflanzenfamilian". 12th ed, Gebrüder Borntraeger Verlag, Berlin.

Schumann, K. (1895) Malvaceae in A. Engler \& K. Prantl NatulichenPflanzenfamilien 3(6): 30-35. Leipzig. Cobenhagen.

Sneath, P.H. \& Sokal, R.R. (1973) Numerical Taxonomy: The Principles and Practice of Numerical Classification. 1st Edition, W. H. Freeman, San Francisco.

Taia, W.K. (2009) General View of Malvaceae Juss. S.L. and Taxonomic Revision of Genus Abutilon Mill. in Saudi Arabia. Journal of King Abdulaziz University Science 21(2):349-363.

Takhtajan, A. (2009) Flowering plants. 2nd ed. Berlin: Springer-Verlag.

Tate, J.A., Aguilar, J.F., Wagstaff, S.J., La Duke, J.C., Bodo Slotta, T.A. \& Simpson, B.B. (2005) Phylogenetic relationships within the tribe Malveae (Malvaceae, subfamily Malvoideae) as inferred from ITS sequence data. American Journal of Botany 92(4): 584-602.

https://doi.org/10.3732/ajb.92.4.584

Ulbrich, E. (1921) Hibiscus. In A. Engler (ed.), Die Pflanzenwelt Afrikas 3(2): 391.
0.7

$0 . V$

0.1

0.9

01 .

011

$01 Y$

$01 \%$

$01 \leq$

010

017

$01 \mathrm{~V}$

011

019

or.

or

orr

OrT

OY

oro

OYT

OYV

orA

org

or.

OrI

OrT

orr

ors

oro 
Zhang, J., Xie, W., Wang, Y. \& Zhao, X. (2015) Potential of start codon targeted (SCoT) markers to estimate genetic diversity and relationships among Chinese Elymus sibiricus accessions. Molecules 20(4): 5987-6001.

Zietkiewicz, E., Rafalski, A. \& Labuda, D. (1994) Genome fingerprinting by simple sequence repeat (SSR)-anchored polymerase chain reaction amplification. Genomics

$0 \leqslant$. 20: 176-183.

$0 \leqslant$

DOI: $\underline{10.1006 / g e n o .1994 .1151}$

FIGUREs captions

$0 \leqslant 0$

FIGURE 1. DNA polymorphism created by five ISSRs primers from the genomic

DNA of the examined species of Malvoideae. Species names are settled and numbered as in TABLE 1.

$0 \leqslant V$

FIGURE 2. DNA polymorphism generated by five SCoT primers from the genomic DNA of the investigated species of Malvaceae. Species names are settled and numbered as in TABLE 1.

00 .

FIGURE 3. UPGMA phenogram viewing the genetic diversity of the 21 species of Malvoideae based on SCoT characters.

FIGURE 4. UPGMA phenogram viewing the genetic diversity of the 21 species of Malvoideae based on ISSR characters.

FIGURE 5. UPGMA phenogram viewing the genetic diversity of the 21 species of Malvoideae based on SCoT and ISSR characters.

TABLE 1. List of taxa used in the study (Chaudary, 1999), a comparison of $t$

TABLE 2. The characteristics of ISSR and SCoT primers sequencing and amplification products generated by the studied taxa.

TABLE 3: Genetic similarity matrix among the studied taxa as FIGUREd according to the Dice coefficient from a combination of SCoT and ISSR primers. Species names 070 from 1-21 as in TABLE 1. 

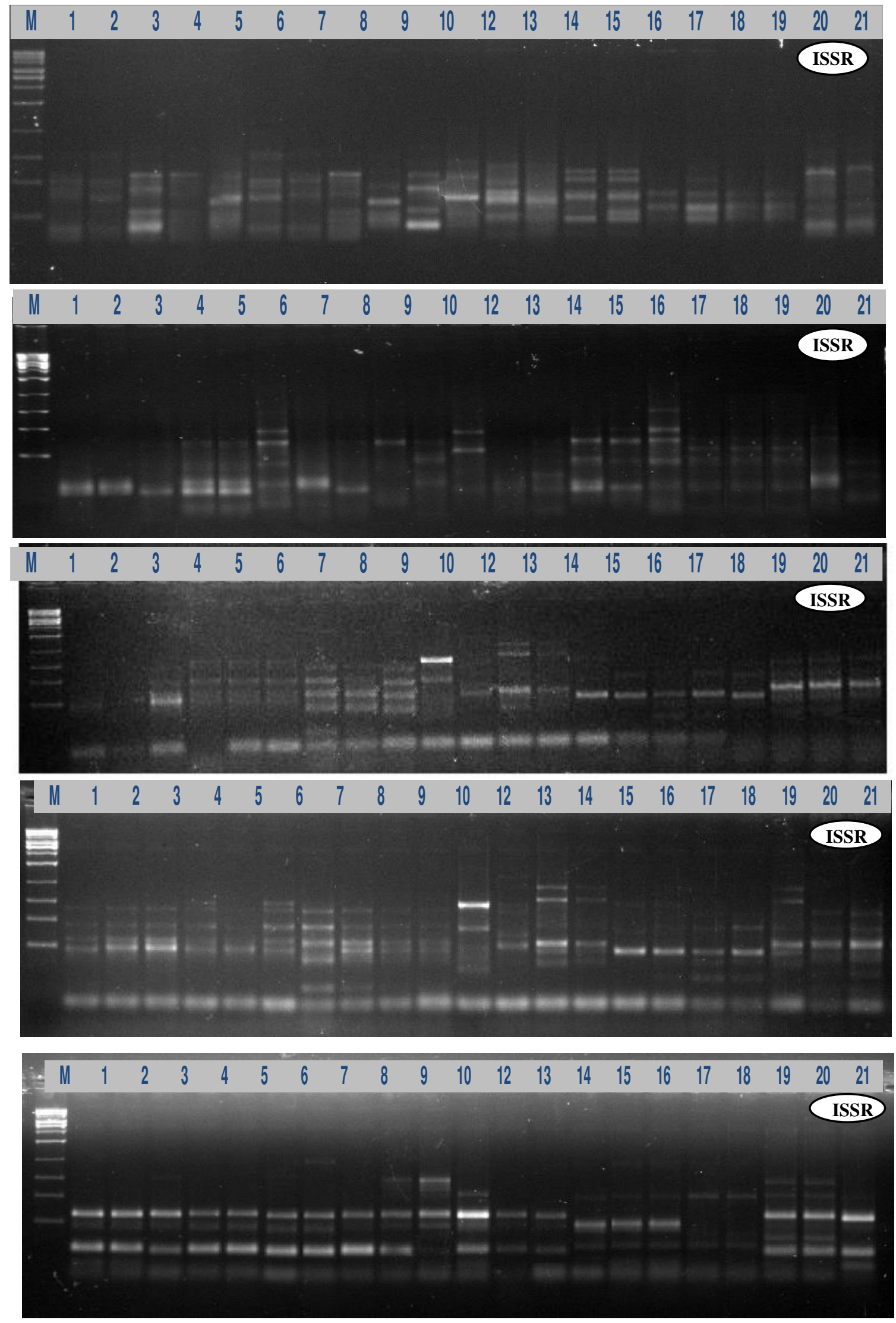
Figure 1. DNA polymorphism generated by five ISSRs primers from the genomic DNA of the investigated species of Malvoideae. Species names are arranged and numbered as in Table 1

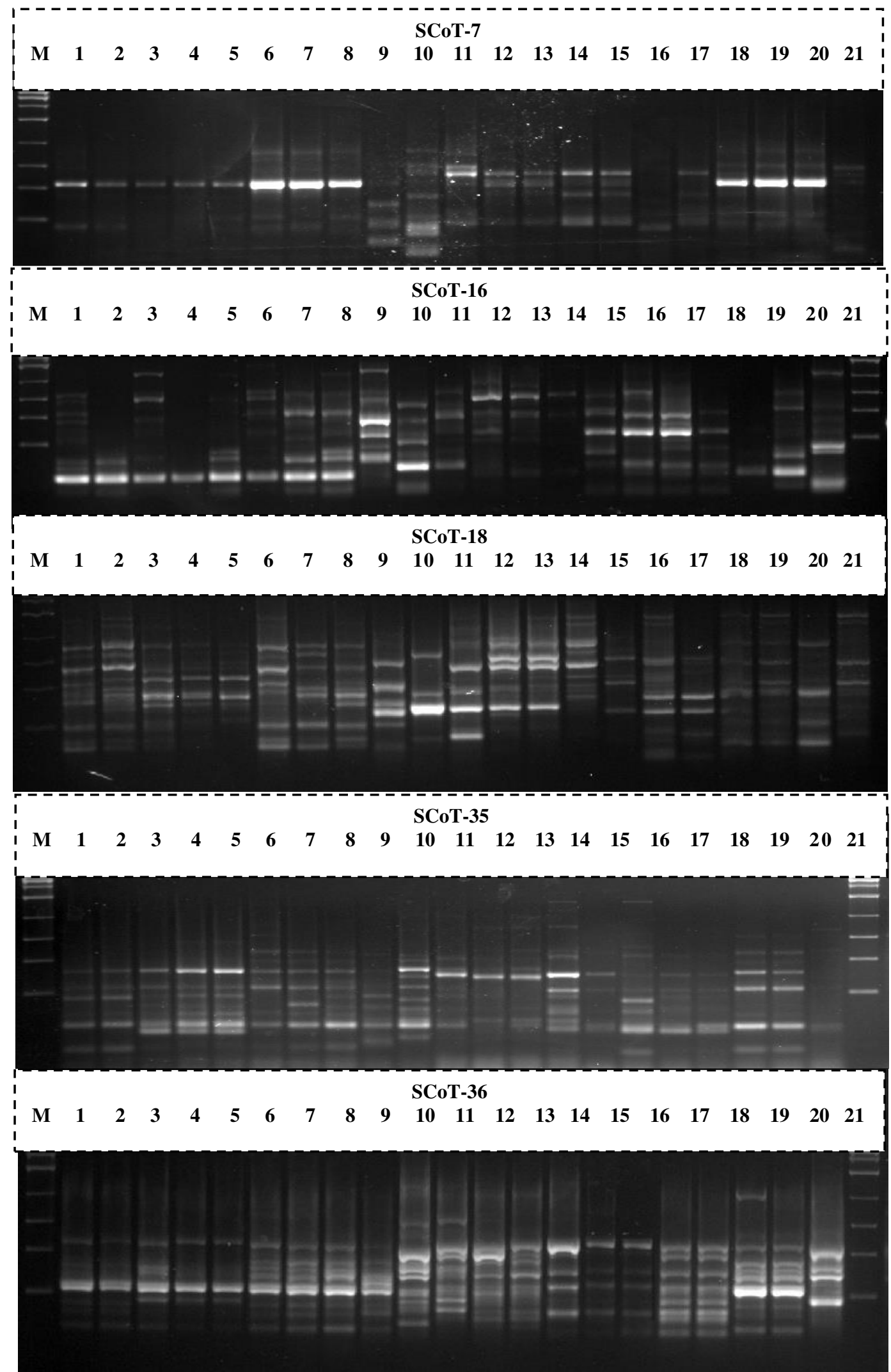


Figure 2. DNA polymorphism generated by five SCoT primers from the genomic 


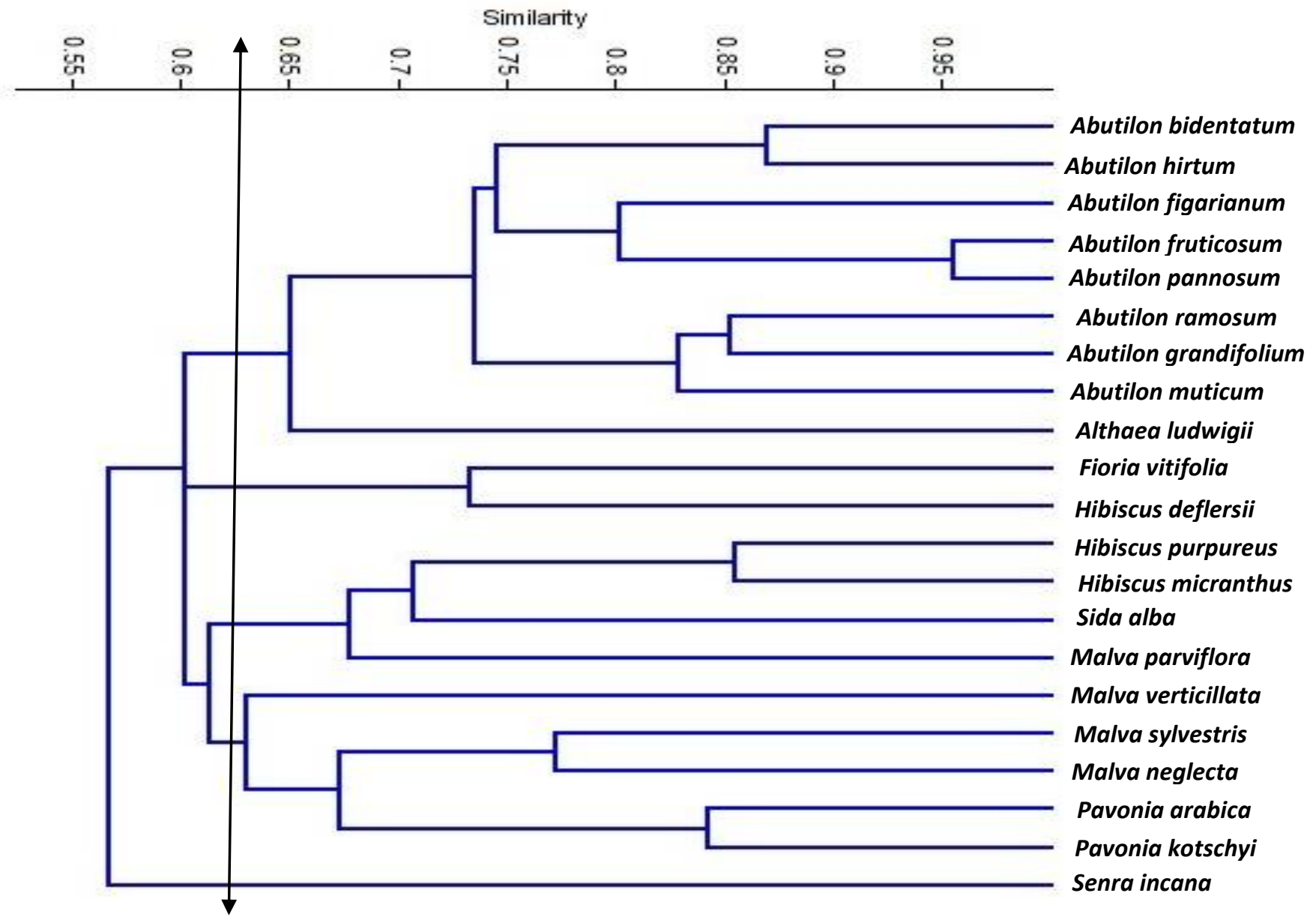

Figure 3. UPGMA phenogram viewing the genetic diversity of the 21 species of Malvoideae based on SCoT characters. 


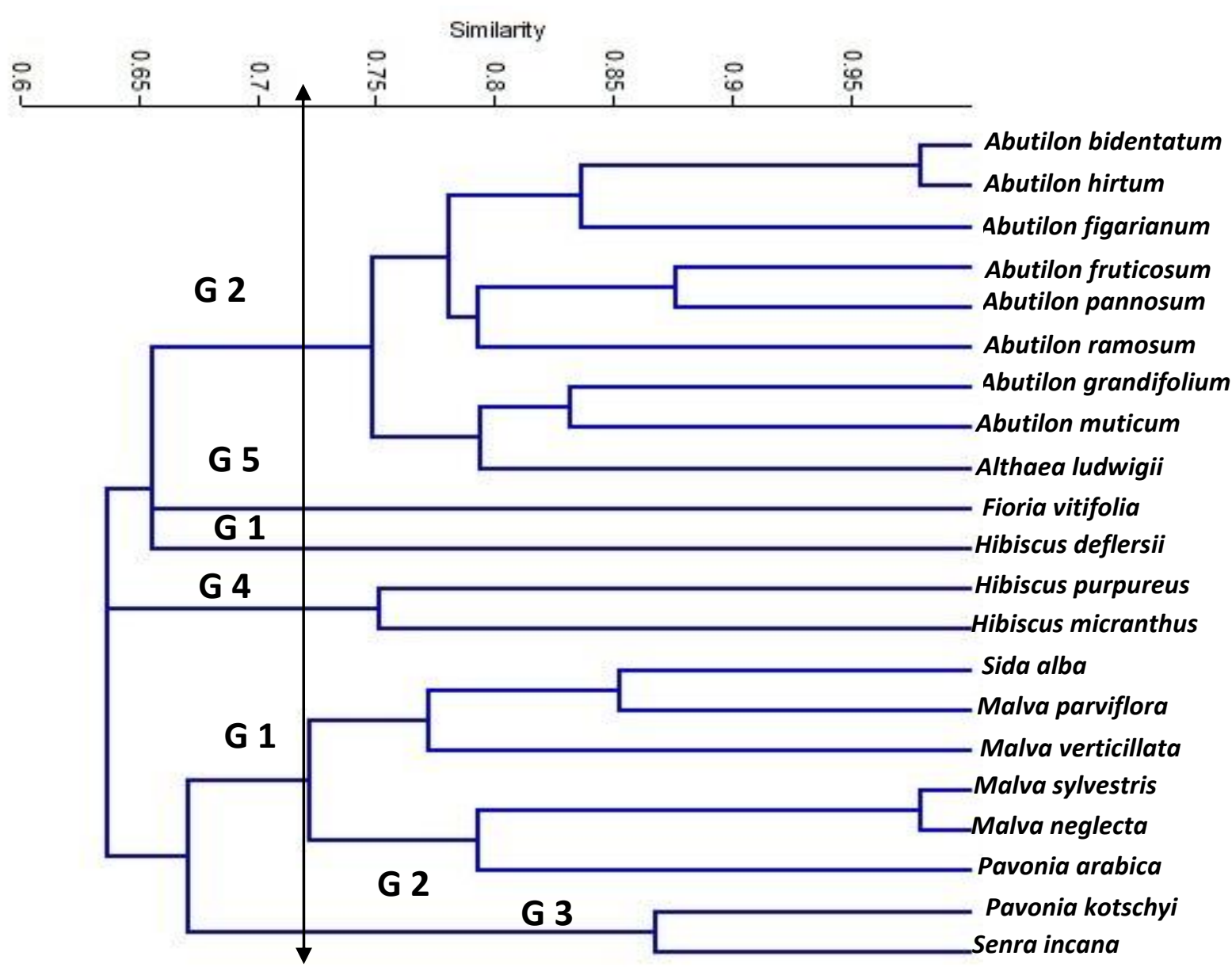




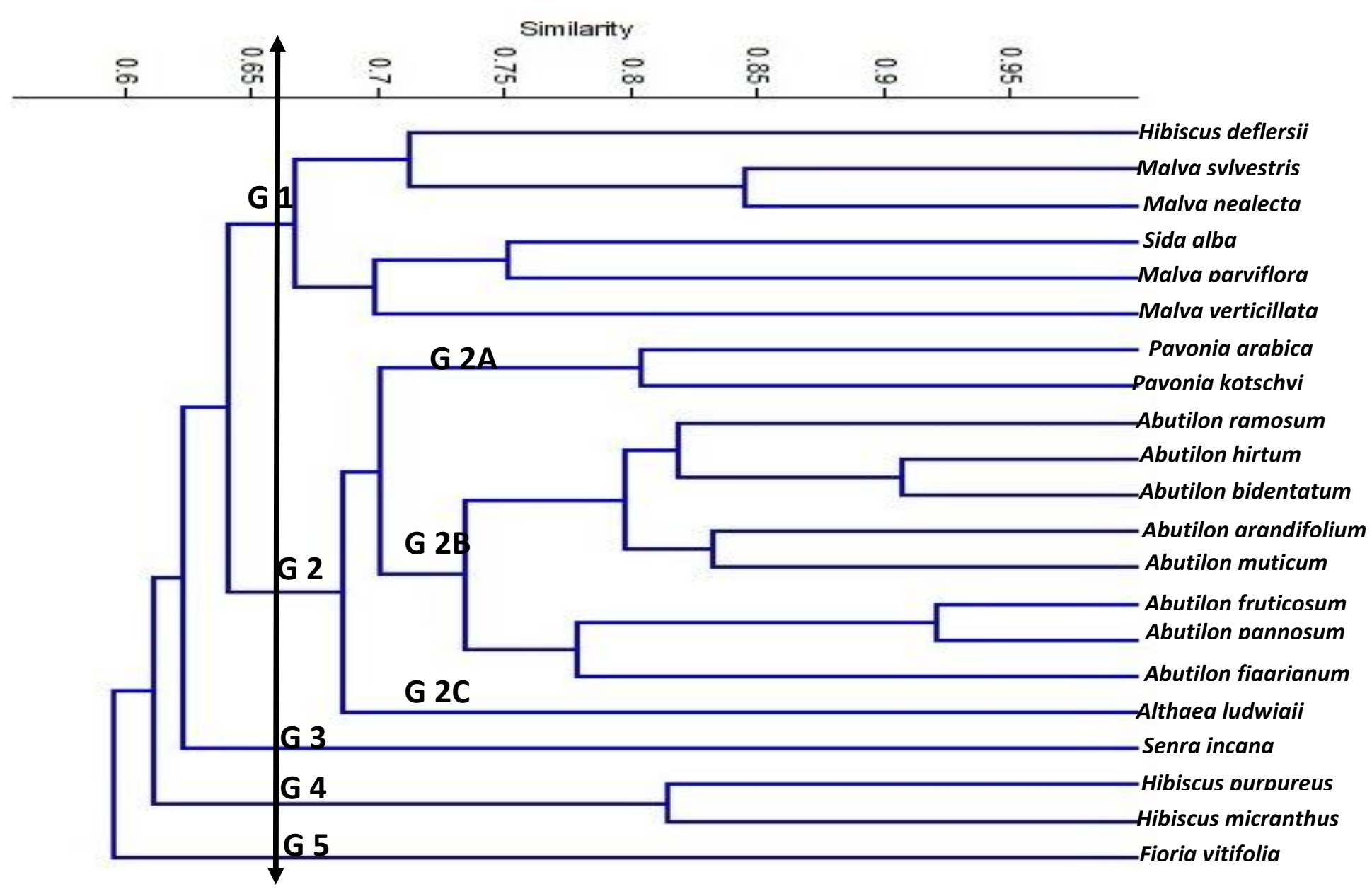

Figure 5. UPGMA phenogram viewing the genetic diversity of the 21 species of Malvoideae based on SCoT and ISSR characters. 
Table 1. List of taxa used in the study (Chaudary, 1999), a comparison of $t$ traditional (Bentham \& Hooker, 1862; Hutchinson, 1967) and phylogenetic classifications (Bayer \& Kubitzhi, 2003; Jennifer et al., 2005; Reveal's system, 2012)

\begin{tabular}{|c|c|c|c|c|c|c|c|}
\hline No & taxa & Source and voucher & $\begin{array}{c}\text { Bentham \&Hooker } \\
(\mathbf{1 8 6 2 )}\end{array}$ & Hutchinson (1967) & $\begin{array}{l}\text { Bayer \& Kubitzhi, 2003; } \\
\text { Jennifer et al. 2005 }\end{array}$ & Reveal's system (2012). & $\begin{array}{l}\text { Present study } \\
\text { SCoT \& ISSR }\end{array}$ \\
\hline 1 & Abutilon bidentatum Hochst. & $\begin{array}{l}\text { Wadii Thalolah near AL-Baha, } \\
\text { Suad Al-Ruzayza, } 11 \text { (UQU) }\end{array}$ & $\begin{array}{l}\text { Tribe: Abutileae } \\
\text { Subtribe: Abutilinae }\end{array}$ & $\begin{array}{l}\text { Tribe: Abutileae } \\
\text { Subtribe: Abutilinae }\end{array}$ & Abutilon alliance & $\begin{array}{l}\text { Tribe:Sideae Subtribe: } \\
\text { Abutilinae }\end{array}$ & G 2 B \\
\hline 2 & Abutilon hirtum (Lam.) Sweet & $\begin{array}{l}\text { Mahil Aseir, Suad Al-Ruzayza, } 8 \\
15 \text { (UQU) }\end{array}$ & $\begin{array}{l}\text { Tribe: Abutileae } \\
\text { Subtribe: Abutilinae }\end{array}$ & $\begin{array}{l}\text { Tribe: Abutileae } \\
\text { Subtribe: Abutilinae }\end{array}$ & Abutilon alliance & $\begin{array}{l}\text { Tribe :Sideae Subtribe: } \\
\text { Abutilinae }\end{array}$ & G 2 B \\
\hline 3 & Abutilon figarianum Webb & $\begin{array}{l}\text { Wadii Qusai, Suad Al-Ruzayza, } 5 \\
\text { (UQU) }\end{array}$ & $\begin{array}{l}\text { Tribe: Abutileae } \\
\text { Subtribe: Abutilinae }\end{array}$ & $\begin{array}{l}\text { Tribe: Abutileae } \\
\text { Subtribe: Abutilinae }\end{array}$ & Abutilon alliance & $\begin{array}{l}\text { Tribe :Sideae Subtribe: } \\
\text { Abutilinae }\end{array}$ & G2 B \\
\hline 4 & Abutilon fruticosum Guill. & $\begin{array}{l}\text { Near Al-Howtah, Alfarhan and J. } \\
\text { Thomas, } 22274 \text { (KSU) }\end{array}$ & $\begin{array}{l}\text { Tribe: Abutileae } \\
\text { Subtribe: Abutilinae }\end{array}$ & $\begin{array}{l}\text { Tribe: Abutileae } \\
\text { Subtribe: Abutilinae }\end{array}$ & Abutilon alliance & $\begin{array}{l}\text { Tribe :Sideae Subtribe: } \\
\text { Abutilinae }\end{array}$ & G2 B \\
\hline 5 & $\begin{array}{l}\text { Abutilon pannosum (G.Forst.) } \\
\text { Schltdl. }\end{array}$ & $\begin{array}{l}\text { Al-Edabi, Suad Al-Ruzayza, } 17 \\
\text { (UQU) }\end{array}$ & $\begin{array}{l}\text { Tribe: Abutileae } \\
\text { Subtribe: Abutilinae }\end{array}$ & $\begin{array}{l}\text { Tribe: Abutileae } \\
\text { Subtribe: Abutilinae }\end{array}$ & Abutilon alliance & $\begin{array}{l}\text { Tribe :Sideae Subtribe: } \\
\text { Abutilinae }\end{array}$ & G 2 B \\
\hline 6 & $\begin{array}{l}\text { Abutilon ramosum (Cav.) } \\
\text { Guill. \& Perr. }\end{array}$ & $\begin{array}{l}\text { Shada mountiain, Suad Al- } \\
\text { Ruzayza,2 (UQU) }\end{array}$ & $\begin{array}{l}\text { Tribe: Abutileae } \\
\text { Subtribe: Abutilinae }\end{array}$ & $\begin{array}{l}\text { Tribe: Abutileae } \\
\text { Subtribe: Abutilinae }\end{array}$ & Abutilon alliance & $\begin{array}{l}\text { Tribe :Sideae Subtribe: } \\
\text { Abutilinae }\end{array}$ & G 2 B \\
\hline 7 & $\begin{array}{l}\text { Abutilon grandifolium } \\
\text { (Willd.) Sweet }\end{array}$ & $\begin{array}{l}\text { Fifa mountain, Suad Al- } \\
\text { Ruzayza,15 (UQU) }\end{array}$ & $\begin{array}{l}\text { Tribe: Abutileae } \\
\text { Subtribe: Abutilinae }\end{array}$ & $\begin{array}{l}\text { Tribe: Abutileae } \\
\text { Subtribe: Abutilinae }\end{array}$ & Abutilon alliance & $\begin{array}{l}\text { Tribe :Sideae Subtribe: } \\
\text { Abutilinae }\end{array}$ & G 2 B \\
\hline 6 & Abutilon muticum Sweet & $\begin{array}{l}\text { Alardah, Suad Al-Ruzayza,6 } \\
\text { (UQU) }\end{array}$ & $\begin{array}{l}\text { Tribe: Abutileae } \\
\text { Subtribe: Abutilinae }\end{array}$ & $\begin{array}{l}\text { Tribe: Abutileae } \\
\text { Subtribe: Abutilinae }\end{array}$ & Abutilon alliance & $\begin{array}{l}\text { Tribe :Sideae Subtribe: } \\
\text { Abutilinae }\end{array}$ & G 2 B \\
\hline 7 & $\begin{array}{l}\text { Abutilon pannosum (G.Forst.) } \\
\text { Schltdl. }\end{array}$ & $\begin{array}{l}\text { Al-Edabi, Suad Al-Ruzayza, } 17 \\
\text { (UQU) }\end{array}$ & $\begin{array}{l}\text { Tribe: Abutileae } \\
\text { Subtribe: Abutilinae }\end{array}$ & $\begin{array}{l}\text { Tribe: Abutileae. } \\
\text { Subtribe: Abutilinae }\end{array}$ & Abutilon alliance & $\begin{array}{l}\text { Tribe :Sideae Subtribe: } \\
\text { Abutilinae }\end{array}$ & G 2 B \\
\hline 8 & $\begin{array}{l}\text { Abutilon ramosum (Cav.) } \\
\text { Guill. }\end{array}$ & $\begin{array}{l}\text { Shada mountiain, Suad Al- } \\
\text { Ruzayza,2 (UQU) }\end{array}$ & $\begin{array}{l}\text { Tribe: Abutileae } \\
\text { Subtribe: Abutilinae }\end{array}$ & $\begin{array}{l}\text { Tribe: Abutileae } \\
\text { Subtribe: Abutilinae }\end{array}$ & Abutilon alliance & $\begin{array}{l}\text { Tribe :Sideae Subtribe: } \\
\text { Abutilinae }\end{array}$ & G 2 B \\
\hline
\end{tabular}




\begin{tabular}{|c|c|c|c|c|c|c|c|}
\hline 9 & Althaea ludwigii $\mathrm{L}$. & $\begin{array}{l}\text { Qassim Road, Suad Al-Ruzayza, } \\
22 \text { (UQU) }\end{array}$ & $\begin{array}{l}\text { Tribe: Malveae } \\
\text { Subtribe: Eumalvinae }\end{array}$ & $\begin{array}{l}\text { Tribe: Malveae } \\
\text { Subtribe: Malvinae }\end{array}$ & Malva alliance & $\begin{array}{l}\text { Tribe :Malveae } \\
\text { Subtribe: Malvinae }\end{array}$ & $\mathrm{G} 2 \mathrm{C}$ \\
\hline 10 & Fioria vitifolia (L.) Mattei & $\begin{array}{l}\text { Al Darb, near Abha, Suad Al- } \\
\text { Ruzayza, } 21 \text { (UQU) }\end{array}$ & Tribe: Hibiscieae & Tribe: Hibisceae & - & Tribe: Hibiscieae & G 5 \\
\hline 11 & Hibiscus deflersii Schweinf. & $\begin{array}{l}\text { Taif, Suad Al-Ruzayza , } 37 \\
\text { (UQU) }\end{array}$ & Tribe: Hibiscieae & Tribe: Hibisceae & - & Tribe: Hibiscieae & G 1 \\
\hline 12 & Hibiscus purpureus $\mathrm{L}$. & $\begin{array}{l}\text { Fifa mountain, Alfarhan and } \mathrm{J} . \\
\text { Thomas, } 999(\mathrm{KSU})\end{array}$ & Tribe: Hibiscieae & Tribe: Hibisceae & - & Tribe: Hibiscieae & G 4 \\
\hline 13 & Hibiscus micranthus L.f. & $\begin{array}{l}\text { Raidah, Suad Al-Ruzayza, } 34 \\
\text { (UQU) }\end{array}$ & Tribe: Hibiscieae & Tribe: Hibisceae & - & Tribe: Hibiscieae & G 4 \\
\hline 14 & Sida alba L., & $\begin{array}{l}\text { Fifa mountain, J. Thomas and R. } \\
\text { Basahi, } 21876 \text { (KSU) }\end{array}$ & $\begin{array}{l}\text { Tribe: Malveae } \\
\text { Subtribe: Sidinae }\end{array}$ & $\begin{array}{l}\text { Tribe: Abutileae. } \\
\text { Subtribe: Sidinae }\end{array}$ & Abutilon alliance & $\begin{array}{l}\text { Tribe :Sideae Subtribe: } \\
\text { Sidinae }\end{array}$ & G 1 \\
\hline 15 & Malva parviflora $\mathrm{L}$. & $\begin{array}{l}\text { Alkarj, Suad Al-Ruzayza, } 29 \\
\text { (UQU) }\end{array}$ & $\begin{array}{l}\text { Tribe: Malveae } \\
\text { Subtribe: Eumalvinae }\end{array}$ & $\begin{array}{l}\text { Tribe: Malveae } \\
\text { Subtribe: Malvinae }\end{array}$ & Malva alliance & $\begin{array}{l}\text { Tribe :Malveae } \\
\text { Subtribe: Malvinae }\end{array}$ & G 1 \\
\hline 16 & Malva verticillata $\mathrm{L}$. , & $\begin{array}{l}\text { AL-ahsaa, Suad Al-Ruzayza, } 32 \\
\text { (UQU) }\end{array}$ & $\begin{array}{l}\text { Tribe: Malveae } \\
\text { Subtribe: Eumalvinae }\end{array}$ & $\begin{array}{l}\text { Tribe: Malveae } \\
\text { Subtribe: Malvinae }\end{array}$ & Malva alliance & $\begin{array}{l}\text { Tribe :Malveae } \\
\text { Subtribe: Malvinae }\end{array}$ & G 1 \\
\hline 17 & Malva sylvestris $\mathrm{L}$. & $\begin{array}{l}\text { Al-Qasim, Buradah, Suad Al- } \\
\text { Ruzayza, } 46 \text { ( UQU) }\end{array}$ & $\begin{array}{l}\text { Tribe: Malveae } \\
\text { Subtribe: Eumalvinae }\end{array}$ & $\begin{array}{l}\text { Tribe: Malveae } \\
\text { Subtribe: Malvinae }\end{array}$ & Malva alliance & $\begin{array}{l}\text { Tribe :Malveae } \\
\text { Subtribe: Malvinae }\end{array}$ & G 1 \\
\hline 18 & Malva neglecta Wallr. & $\begin{array}{l}\text { Syll., Ushaqur, Suad Al-Ruzayza, } \\
2 \text { (UQU) }\end{array}$ & $\begin{array}{l}\text { Tribe: Malveae } \\
\text { Subtribe: Eumalvinae }\end{array}$ & $\begin{array}{l}\text { Tribe: Malveae Subtribe: } \\
\text { Malvinae }\end{array}$ & Malva alliance & $\begin{array}{l}\text { Tribe :Malveae } \\
\text { Subtribe: Malvinae }\end{array}$ & G 1 \\
\hline 19 & Pavonia arabica Hochst. & $\begin{array}{l}\text { Wadi Bani Zaher, S. Chaudhary, } \\
7087 \text { (RAWRC) }\end{array}$ & Tribe: Ureneae & Tribe: Ureneae & - & Tribe: Hibiscieae & G $2 \mathrm{~A}$ \\
\hline 20 & Pavonia kotschyi Hochst. & $\begin{array}{l}\text { Jeddah, Suad Al-Ruzayza, } 40 \\
\text { (UQU) }\end{array}$ & Tribe: Ureneae & Tribe: Ureneae & & Tribe: Hibiscieae & G 2A \\
\hline 21 & Senra incana Cav. & $\begin{array}{l}\text { Harrat Al-Shara, Suad Al-Ruzayza, } \\
41 \text { (UQU) }\end{array}$ & Tribe: Hibiscieae & Tribe: Hibiscieae & & Tribe: Gossypieae & G 3 \\
\hline
\end{tabular}


Table 2. The characteristics of ISSR and SCoT primers sequencing and amplification products generated by the studied taxa.

\begin{tabular}{|c|c|c|c|c|c|c|}
\hline Marker type & Prime & Sequence 5'-3' & $\begin{array}{c}\text { Total no. of } \\
\text { bands }\end{array}$ & $\begin{array}{c}\text { Monomorphic } \\
\text { bands }\end{array}$ & $\begin{array}{c}\text { Polymorphic } \\
\text { bands }\end{array}$ & $\begin{array}{c}\% \text { of } \\
\text { Polymorphism }\end{array}$ \\
\hline \multirow{5}{*}{ ISSR } & ISSR- 1 & 5'-AGAGAGAGAGAGAGAGYC-3' & 11 & 1 & $\mathbf{1 0}$ & $91 \%$ \\
\hline & ISSR- 2 & 5'-AGAGAGAGAGAGAGAGYG-3' & 11 & 2 & 9 & $82 \%$ \\
\hline & ISSR- 3 & 5'-ACACACACACACACACYT-3' & 12 & 2 & 10 & $\mathbf{8 3 \%}$ \\
\hline & ISSR- 4 & 5'-ACACACACACACACACYG-3' & 14 & 2 & 12 & $86 \%$ \\
\hline & ISSR- 5 & 5'-GTGTGTGTGTGTGTGTYG-3' & 12 & 4 & 8 & $67 \%$ \\
\hline \multirow{5}{*}{ SCoT } & SCoT-7 & ACAATGGCTACCACTGAC & 15 & 1 & 14 & $93 \%$ \\
\hline & SCoT-16 & CCATGGCTACCACCGGCA & 21 & 2 & 19 & $90 \%$ \\
\hline & SCoT-18 & CCATGGCTACCACTAGCA & 22 & 2 & 20 & $91 \%$ \\
\hline & SCoT-35 & AACCATGGCTACCACCAC & 23 & 3 & 20 & $87 \%$ \\
\hline & SCoT-36 & CACCATGGCTACCACCAT & 19 & 3 & 16 & $84 \%$ \\
\hline \multicolumn{3}{|l|}{ Total number } & 160 & 22 & 138 & \\
\hline
\end{tabular}

A: Adenine, T: Thymine, G: Guanine and C: Cytosine Y: (C or T) 
Table 3: Genetic similarity matrix among the studied taxa as computed according to Dice coefficient from combined of SCoT and ISSR primers. Species names from 1-21 as in Table 1.

\begin{tabular}{|c|c|c|c|c|c|c|c|c|c|c|c|c|c|c|c|c|c|c|c|c|c|}
\hline & 1 & 2 & 3 & 4 & 5 & 6 & 7 & 8 & 9 & 10 & 11 & 12 & 13 & 14 & 15 & 16 & 17 & 18 & 19 & 20 & 21 \\
\hline 1 & 1.00 & & & & & & & & & & & & & & & & & & & & \\
\hline 2 & 0.91 & 1.00 & & & & & & & & & & & & & & & & & & & \\
\hline 3 & 0.78 & 0.78 & 1.00 & & & & & & & & & & & & & & & & & & \\
\hline 4 & 0.73 & 0.76 & 0.81 & 1.00 & & & & & & & & & & & & & & & & & \\
\hline 5 & 0.74 & 0.77 & 0.75 & 0.92 & 1.00 & & & & & & & & & & & & & & & & \\
\hline 6 & 0.81 & 0.82 & 0.73 & 0.71 & 0.69 & 1.00 & & & & & & & & & & & & & & & \\
\hline 7 & 0.81 & 0.79 & 0.73 & 0.68 & 0.70 & 0.82 & 1.00 & & & & & & & & & & & & & & \\
\hline 8 & 0.81 & 0.78 & 0.78 & 0.71 & 0.72 & 0.78 & 0.83 & 1.00 & & & & & & & & & & & & & \\
\hline 9 & 0.68 & 0.66 & 0.67 & 0.63 & 0.68 & 0.69 & 0.71 & 0.77 & 1.00 & & & & & & & & & & & & \\
\hline 10 & 0.62 & 0.60 & 0.60 & 0.56 & 0.56 & 0.63 & 0.60 & 0.64 & 0.57 & 1.00 & & & & & & & & & & & \\
\hline 11 & 0.67 & 0.69 & 0.57 & 0.57 & 0.58 & 0.70 & 0.62 & 0.62 & 0.63 & 0.69 & 1.00 & & & & & & & & & & \\
\hline 12 & 0.63 & 0.59 & 0.56 & 0.54 & 0.53 & 0.59 & 0.58 & 0.60 & 0.62 & 0.53 & 0.65 & 1.00 & & & & & & & & & \\
\hline 13 & 0.60 & 0.63 & 0.57 & 0.60 & 0.63 & 0.61 & 0.58 & 0.61 & 0.63 & 0.54 & 0.67 & 0.81 & 1.00 & & & & & & & & \\
\hline 14 & 0.60 & 0.63 & 0.57 & 0.62 & 0.63 & 0.64 & 0.59 & 0.59 & 0.59 & 0.54 & 0.61 & 0.68 & 0.70 & 1.00 & & & & & & & \\
\hline 15 & 0.64 & 0.64 & 0.61 & 0.64 & 0.67 & 0.65 & 0.60 & 0.65 & 0.68 & 0.59 & 0.63 & 0.68 & 0.63 & 0.75 & 1.00 & & & & & & \\
\hline 16 & 0.61 & 0.66 & 0.62 & 0.64 & 0.66 & 0.62 & 0.57 & 0.60 & 0.59 & 0.59 & 0.57 & 0.51 & 0.56 & 0.68 & 0.71 & 1.00 & & & & & \\
\hline 17 & 0.68 & 0.65 & 0.59 & 0.62 & 0.64 & 0.60 & 0.61 & 0.62 & 0.64 & 0.61 & 0.70 & 0.63 & 0.63 & 0.64 & 0.77 & 0.70 & 1.00 & & & & \\
\hline 18 & 0.74 & 0.74 & 0.67 & 0.65 & 0.68 & 0.70 & 0.65 & 0.73 & 0.67 & 0.61 & 0.72 & 0.62 & 0.66 & 0.64 & 0.73 & 0.70 & 0.84 & 1.00 & & & \\
\hline 19 & 0.70 & 0.71 & 0.67 & 0.60 & 0.62 & 0.75 & 0.69 & 0.72 & 0.67 & 0.60 & 0.67 & 0.59 & 0.67 & 0.64 & 0.60 & 0.61 & 0.66 & 0.79 & 1.00 & & \\
\hline 20 & 0.71 & 0.70 & 0.70 & 0.68 & 0.66 & 0.75 & 0.79 & 0.76 & 0.68 & 0.61 & 0.62 & 0.59 & 0.58 & 0.64 & 0.65 & 0.62 & 0.62 & 0.71 & 0.80 & 1.00 & \\
\hline 21 & 0.63 & 0.62 & 0.66 & 0.61 & 0.57 & 0.63 & 0.64 & 0.64 & 0.61 & 0.58 & 0.58 & 0.61 & 0.60 & 0.61 & 0.59 & 0.58 & 0.66 & 0.63 & 0.63 & 0.67 & 1.00 \\
\hline
\end{tabular}


Figures
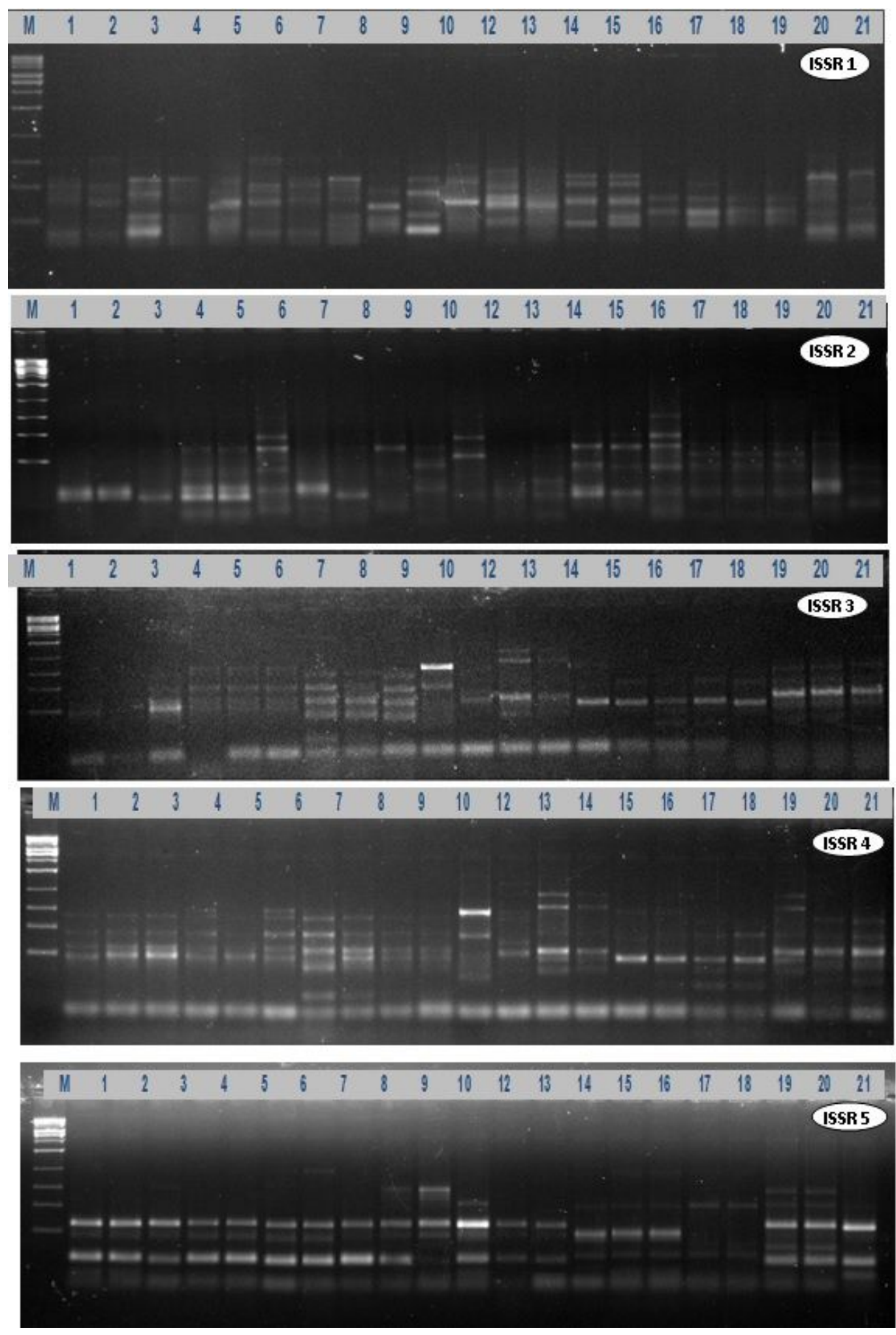

\section{Figure 1}

DNA polymorphism generated by five ISSRs primers from the genomic DNA of the investigated species of Malvoideae. Species names are arranged and numbered as in Table 1 


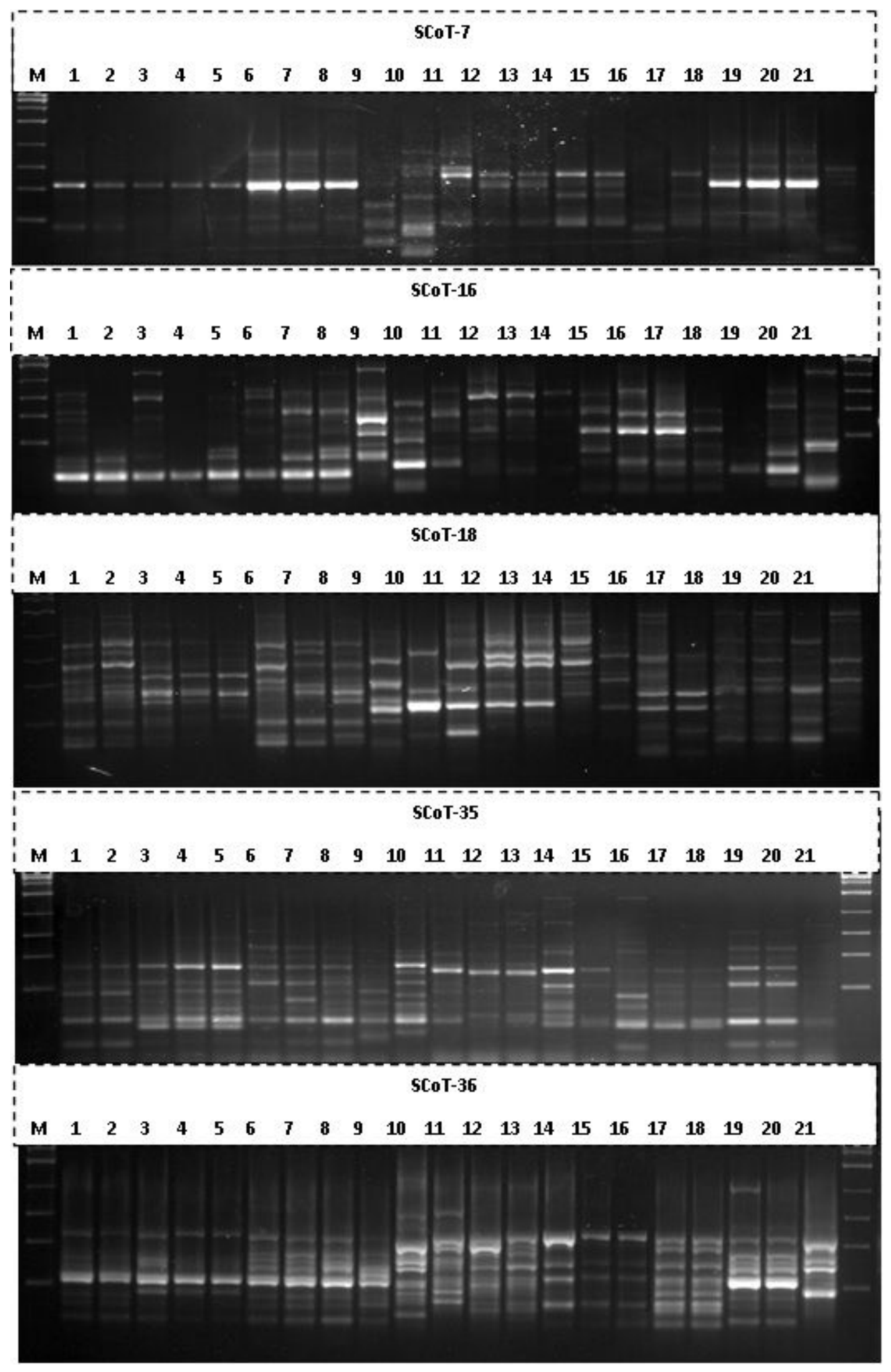

\section{Figure 2}

DNA polymorphism generated by five SCoT primers from the genomic DNA of the investigated species of Malvaceae. Species names are arranged and numbered as in Table 1 


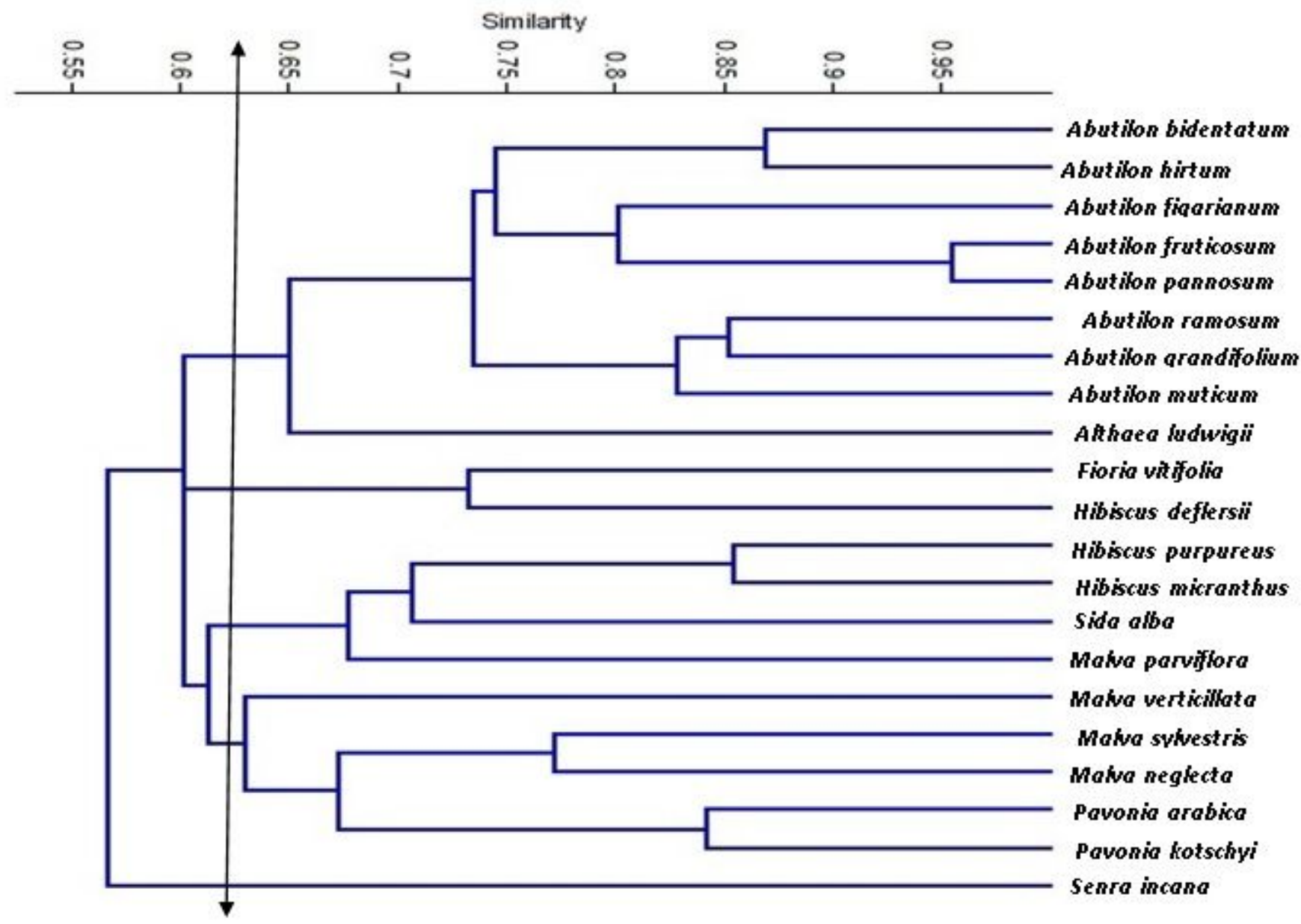

Figure 3

UPGMA phenogram viewing the genetic diversity of the 21 species of Malvoideae based on SCoT characters. 


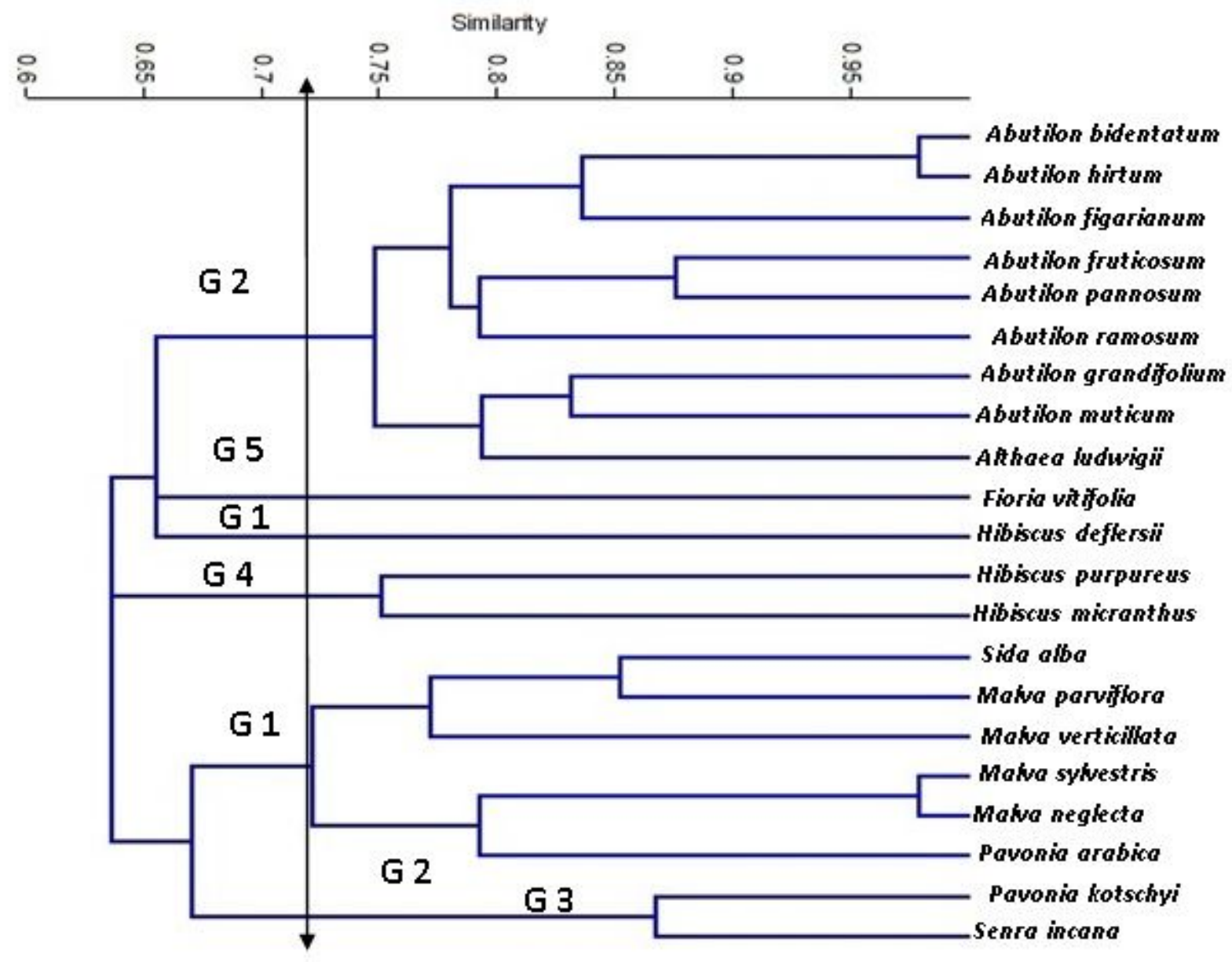

Figure 4

UPGMA phenogram viewing the genetic diversity of the 21 species of Malvoideae based on ISSR characters. 


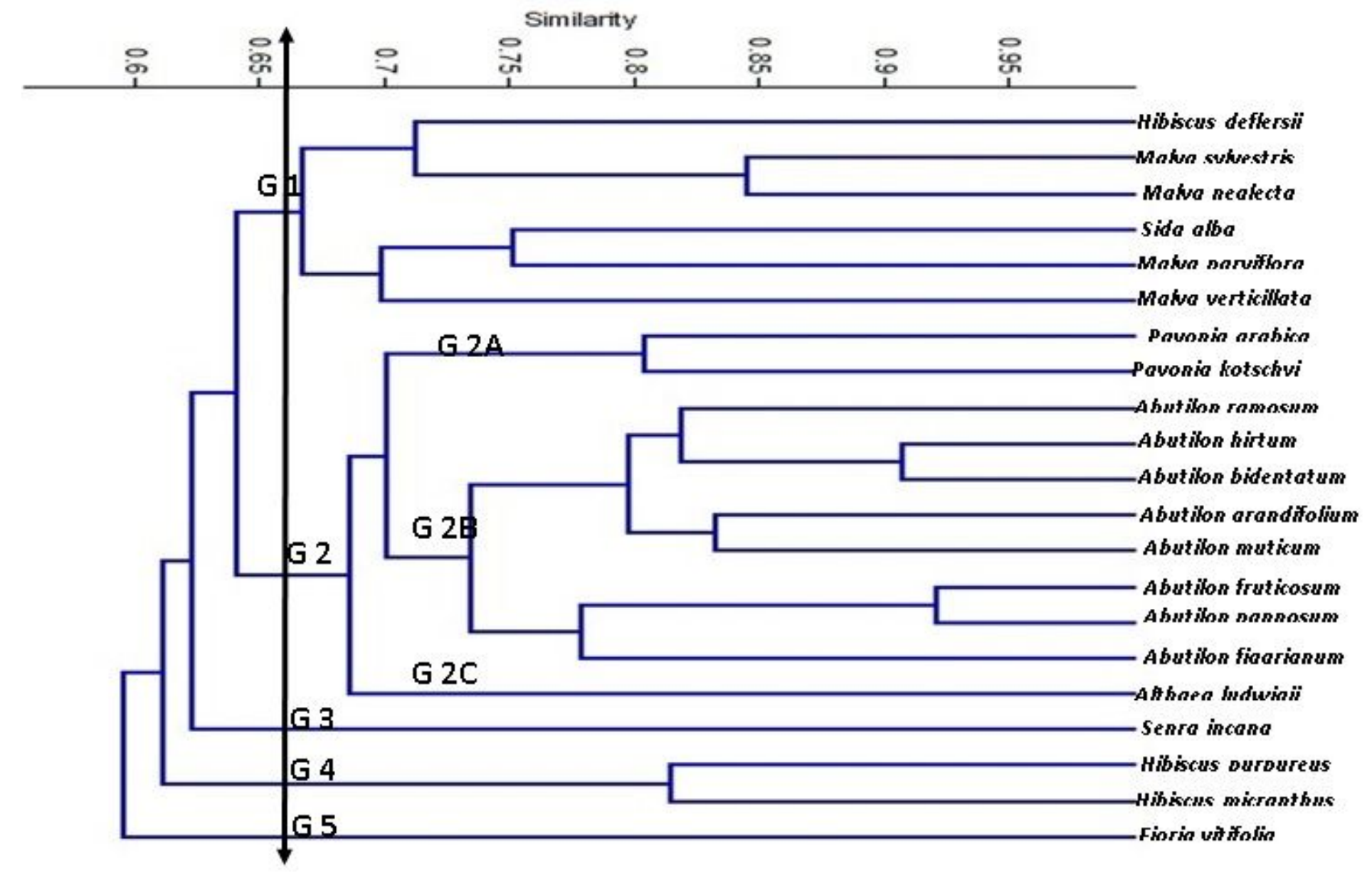

Figure 5

UPGMA phenogram viewing the genetic diversity of the 21 species of Malvoideae based on SCoT and ISSR characters.

\section{Supplementary Files}

This is a list of supplementary files associated with this preprint. Click to download.

- tables.doc 